\title{
High Flow Nasal Oxygen Therapy in Pediatric Intensive Care Unit
}

\section{Çocuk Yoğun Bakım Ünitesinde Yüksek Akışlı Nazal Oksijen Tedavisi}

\author{
(D) Ayhan Yaman
}

İstinye University Faculty of Medicine, Bahçeşehir Liv Hospital, Pediatric Intensive Care Unit, İstanbul, Turkey

\section{Abstract}

Objective: Acute respiratory failure is the most common reason for hospitalization to pediatric intensive care units. Invasive and non-invasive respiratory support methods are used for the treatment of patients with acute respiratory failure findings. The aim of this study is to evaluate the effectiveness of high flow nasal cannula (HFNC) oxygen therapy in pediatric intensive care.

Method: This retrospective observational study was conducted between February 2017 and January 2018 in pediatric intensive care unit of Bahçeşehir Liv Hospital, İstinye University Faculty of Medicine. Patients aged between 1 month and 18 years, who received HFNC oxygen therapy for respiratory support in the pediatric intensive care unit, were included in the study.

Results: HFNC therapy was received by 67 patients during one year of the study. $58.2 \%$ of the patients were male. The mean age of the patients was 37.2 months ( $R, 1-192)$, and their average body weight was $11.8 \mathrm{~kg}$ ( $R, 2.8-50) .65 .7 \%$ of patients had an underlying disease. The most underlying disease was neurological disease with the rate of $35.8 \% .94 \%$ of our patients received HFNC therapy due to acute respiratory failure, $3 \%$ due to acute heart failure and $3 \%$ due to shock. $40.3 \%$ of our patients received HFNC therapy due to pneumonia, $16.4 \%$ due to bronchopneumonia, $14.9 \%$ due to bronchiolitis, and $11.9 \%$ due to postextubation. $71.6 \%$ of patients receiving HFNC therapy improved their clinical findings without intubation. After HFNC therapy, there was a statistically considerable decrease in the respiratory rate, heart rate and retraction of the patients. HFNC therapy failure rates were statistically significantly higher in patients with underlying disease and especially in those with cardiac disease.

Conclusion: As a result, it is known that HFNC therapy has been used effectively in children in recent years, and it provides improvement in vital findings and blood gas parameters. In our study, $71.6 \%$ of our patients benefited from HFNC therapy.

Keywords: High flow nasal cannula oxygen therapy, pediatric intensive care, respiratory failure

\section{Öz}

Amaç: Çocuk yoğun bakım ünitelerine yatışın en sık nedeni akut solunum yetmezliğidir. Akut solunum yetmezliği bulguları olan hastalara tedavi amaçlı invazif ve non-invazif solunum destek yöntemleri kullanılmaktadır. Bu çalışmanın amacı çocuk yoğun bakımda yüksek akışı nazal kanül oksijen (YANKO) tedavisinin etkinliğini değerlendirmektir.

Yöntem: Bu retrospektif gözlemsel çalışma, Şubat 2017 ile Ocak 2018 tarihleri arasında İstinye Üniversitesi Tıp Fakültesi, Bahçeşehir Liv Hastanesi, Çocuk Yoğun Bakım Ünitesi'nde gerçekleştirilmiştir. Bir ay ile 18 yaş arasında çocuk yoğun bakım ünitesinde solunum desteği amacıyla yüksek akışlı nazal kanül oksijen tedavisi alan hastalar çalışmaya alındı.

Bulgular: Bir yıllık çalışma süresi içerisinde 67 hastamız YANKO tedavisi aldı. Hastaların \%58,2'si erkekti. Hastaların ortalama yaşları 37,2 ay $(R, 1-192)$, ortalama vücut ağırlıkları $11,8 \mathrm{~kg}(R, 2,8-50)$ idi. Hastaların \%65,7'sinde altta yatan bir hastalık vardı. En sık altta yatan hastalık \%35,8 ile nörolojik hastalık grubu oluşturuyordu. Hastalarımızın \%94'ü akut solunum yetmezliği, \%3'ü akut kalp yetmezliği ve \%3'ü şok nedeniyle YANKO tedavisi aldı. Hastalarımızın \%40,3'ü pnömoni, \%16,4'ü bronkopnömoni, \%14,9'u bronşiolit, \%11,9'u ekstübasyon sonrası akut solunum yetmezliği nedeniyle YANKO tedavisi aldı. YANKO tedavisi alan hastaların \%71,6'sı entübe olmadan klinik bulguları düzeldi. YANKO sonrası hastaların solunum sayısı, kalp hızı, retraksiyon düzeylerinde istatistiksel olarak anlamlı düşüş saptandı. Altta yatan hastalığı olan ve özellikle kardiyak hastalığı olanlarda YANKO tedavisi başarısızlık oranları istatistiksel olarak anlamlı yüksek bulundu.

Sonuç: Sonuç olarak, son yıllarda YANKO tedavisinin çocuklarda etkin bir şekilde kullanıldığı, vital bulgular ve kan gazı parametrelerinde düzelme sağladığı bilinmektedir. Çalışmamızda hastalarımızın \%71,6'sı YANKO tedavisinden fayda gördü.

Anahtar kelimeler: Çocuk yoğun bakım, solunum yetmezliği, yüksek akışı nazal kanül oksijen tedavisi

Address for Correspondence: Ayhan Yaman, İstinye University Faculty of Medicine, Bahçeşehir Liv Hospital, Pediatric Intensive Care Unit, İstanbul, Turkey E-mail: dryamanayhan@yahoo.com.tr ORCID: orcid.org/0000-0002-5651-1286 Received: 03.10.2020 Accepted: 19.12.2020

Cite this article as: Yaman A. High Flow Nasal Oxygen Therapy in Pediatric Intensive Care Unit. Bagcilar Med Bull 2021;6(1):42-47.

${ }^{\odot}$ Copyright 2021 by the Health Sciences University Turkey, Bagcilar Training and Research Hospital

Bagcilar Medical Bulletin published by Galenos Publishing House. 


\section{Introduction}

Acute respiratory failure is one of the most important causes of mortality and morbidity in children, and it is defined as the inability of the respiratory system to provide adequate oxygen distribution or carbon dioxide excretion (1). The most common reason for hospitalization to pediatric intensive care units is acute respiratory failure. Invasive and non-invasive respiratory support methods are used for the treatment of patients with acute respiratory failure symptoms (2). Non-invasive respiratory support methods have become more preferable due to the disadvantages and high risk of complications associated with invasive mechanical ventilation (MV) (3). In the literature, most of the data on non-invasive MV are based on adult studies. Data on non-invasive MV treatment in children are limited $(4,5)$. HFNC oxygenation therapy for non-invasive MV application in children is a treatment method that has found an increasing usage area both in the world and in our country. It is observed that this treatment, which was initially applied in preterm newborns, was started to be applied frequently in intensive care units, child and adult emergency services and other services over time (6-8). The aim of this study is to evaluate the effectiveness of HFNC oxygen therapy in pediatric intensive care.

\section{Materials and Methods}

This retrospective observational study was conducted between February 2017 and January 2018 in pediatric intensive care unit of Bahçeşehir Liv Hospital, İstinye University Faculty of Medicine. The efficacy of HFNC oxygen therapy was investigated in patients in need of respiratory support in a 19-bed pediatric intensive care unit where hospitalized critical pediatric patients aged between 1 month and 18 years. Treatment consent was obtained from the relatives of all patients in the intensive care hospitalization. Age, gender, body weights, underlying disease, reason for admission to intensive care, respiratory failure type, vital signs, blood gas values, reason for admission to HFNC therapy, HFNC application parameters, used prongs, vital signs before and after HFNC and blood gas values were examined. Whether patients received sedation during HFNC support, their nutritional status, and duration of stay at HFNC were evaluated. Success status of patients under HFNC therapy was recorded. Patients between the ages of 1 month and 18 years who had acute respiratory failure, shock, and who needed respiratory support after extubation were included in the study.

Patients with severe respiratory failure who needed intubation and patients with decompensated shock were excluded from the study. Fisher \& Paykel Airvo 2 system (Fisher \& Paykel Healthcare Ltd, New Zealand) device was used for HFNC treatment. Fisher \& Paykel nasal cannulas suitable for age and weight were used. Ethics committee approval for this study was obtained from İstinye University.

\section{Statistical Analysis}

SPSS 15.0 windows program was used for statistical analysis. As descriptive statistics, numbers and percentages for categorical variables, and mean, standard deviation, minimum, maximum and median for numerical variables were given. Student's t-test was performed for two independent groups of numerical variables when normal distribution criterion was satisfied, and Mann-Whitney U test was performed when the two groups did not satisfy the normal distribution criterion. Paired t-test was performed for dependent group analysis of numerical variables when their difference satisfied the normal distribution criterion, and Wilcoxon analysis was performed when the criterion was not satisfied. Alpha significance level was regarded as $\mathrm{p}<0.05$.

\section{Results}

HFNC therapy was received by 67 patients during one year of the study. The demographic characteristics of the patients are given in Table $1.58 .2 \%$ of the patients were male. The mean age of the patients was 37.2 months (R, 1-192), and their average body weight was $11.8 \mathrm{~kg}(\mathrm{R}, 2.8-50)$. There was

\begin{tabular}{lll} 
Table 1. Demographic characteristics & $\mathbf{n}(\%)$ \\
Gender & Male & $39(58.2)$ \\
& Female & $28(41.8)$ \\
Age (month) & - & $37.2 \pm 48.2$ \\
Weight (kg) & - & $(1-192)$ \\
& & $11.8 \pm 11.0$ \\
& No & $(2.8-50)$ \\
& Neurological disease & $24(35.8)$ \\
Underlying disease & Liver disease & $1(1.5)$ \\
& Cardiac disease & $13(19.4)$ \\
& Immune deficiency & $1(1.5)$ \\
& Malnutrition & $3(4.5)$ \\
The reason for & Other & $2(3.0)$ \\
hospitalization in & Respiratory failure & $63(94.0)$ \\
intensive care & Heart failure & $2(3.0)$ \\
Respiratory failure type & Shock & $2(3.0)$ \\
& Type 1 & $40(61.5)$ \\
\hline & Type 2 & $25(38.5)$ \\
\hline
\end{tabular}

of patients $n(\%)$ 
an underlying disease in $65.7 \%$ of the patients. The most underlying disease was neurological disease with the rate of $35.8 \%$. 94\% of our patients received HFNC therapy due to acute respiratory failure, $3 \%$ due to acute heart failure and $3 \%$ due to shock. $61.5 \%$ of patients with respiratory failure were in type 1 (hypoxic) respiratory failure.

$40.3 \%$ of our patients received HFNC therapy due to pneumonia, $16.4 \%$ due to bronchopneumonia, $14.9 \%$ due

Table 2. Features of HFNC therapy applied to children

\begin{tabular}{lll} 
& & $\mathbf{n}(\%)$ \\
\hline & Proumonia & $27(40.3)$ \\
& Bronchopneumonia & $11(16.4)$ \\
& Pulmonary edema & $5(7.5)$ \\
HFNC indication & Postextubation & $8(11.9)$ \\
& Aspiration & $1(1.5)$ \\
HFNC flow & Atelectasis & $1(1.5)$ \\
FiO ${ }_{2}$ & Shock & $2(3.0)$ \\
& Hypoventilation & $2(3.0)$ \\
Sedation & - & $5.6 \pm 8.7(1-25)$ \\
& - & $25.4 \pm 12.1(10-60)$ \\
Nuration of stay in HFNC & $80.7 \pm 8.8(58-95)$ \\
Intubation & - & $51(76.1)$ \\
& No & $11(16.4)$ \\
\hline & Ketamine & $5(7.5)$ \\
& Midazolam & $47(70.1)$ \\
& Yes & $20(29.9)$ \\
& No & $48(71.6)$ \\
& No & $19(28.4)$ \\
\hline & Yes & \\
& &
\end{tabular}

HFNC: High flow nasal cannula, $\mathrm{FiO}_{2}$ : Fraction of Inspired Oxygen to bronchiolitis, and $11.9 \%$ due to postextubation. The mean duration of HFNC treatment was 5.6 hours (R, 1-25), and the mean flow was $25.4(\mathrm{R}, 10-60) \mathrm{Lt} / \mathrm{min} .76 .1 \%$ of the patients did not receive sedation during HFNC therapy. Ketamine and midazolam were used in patients receiving sedation. $70.1 \%$ of the patients were fed under HFNC treatment. $71.6 \%$ of patients receiving HFNC therapy improved their clinical findings without intubation. HFNC therapy failed in $28.4 \%$ of our patients and they were intubated (Table 2).

Vital findings and blood gases of patients before and after HFNC treatment are shown in Table 3. After high flow nasal oxygen therapy, a decrease was found in the respiratory and heart rates of the patients. In addition, retractions decreased and there was an increase in saturation values. Considerable improvements in $\mathrm{pH}, \mathrm{PO}_{2}$ and saturation values were observed in blood gas parameters. Gender, age and weight were not statistically different in patients for whom the treatment was successful and failed. Table 4 shows that HFNC treatment failure rates were found to be statistically significantly higher in patients with underlying disease and especially in those with cardiac disease.

After HFNC, there was a statistically significant decrease in the respiratory rate, heart rate and retraction levels of the patients. Table 5 shows that systolic blood pressure, oxygen saturation, blood gas levels, $\mathrm{pH}$, and oxygen saturation levels were statistically significantly increased $(\mathrm{p}=0.001$, $\mathrm{p}<0.001, \mathrm{p}=0.002 \mathrm{p}<0.001, \mathrm{p}=0.001, \mathrm{p}=0.011, \mathrm{p}=0.016$, respectively).

Vital signs and blood gas parameters of the successful and unsuccessful patients after HFNC are given in Table

Table 3. Vital findings and blood gas levels before and after HFNC treatment

\begin{tabular}{|c|c|c|c|c|}
\hline & \multicolumn{2}{|c|}{ Before HFNC } & \multicolumn{2}{|l|}{ After HFNC } \\
\hline & Mean \pm SD & Min-max (median) & Mean \pm SD & Min-max (median) \\
\hline Respiration rate & $43.2 \pm 16.2$ & $20-90(43)$ & $34.5 \pm 13.3$ & $16-100(32)$ \\
\hline Systolic blood pressure & $102.9 \pm 18.0$ & $44-142(101)$ & $108.4 \pm 14.8$ & $83-143(107)$ \\
\hline Retraction & $1.76 \pm 0.52$ & $1-3(2)$ & $0.96 \pm 0.56$ & $0-2(1)$ \\
\hline $\mathrm{PCO}_{2}$ & $46.4 \pm 19.5$ & $20-132(43)$ & $43.4 \pm 10.2$ & $26-74(43)$ \\
\hline $\mathrm{PO}_{2}$ & $84.5 \pm 54.2$ & $26-288(65)$ & $96.2 \pm 64.9$ & $22-354(86)$ \\
\hline $\mathrm{HCO}_{3}$ & $24.6 \pm 7.0$ & $10-48(24)$ & $26.1 \pm 4.8$ & $18-38(25)$ \\
\hline
\end{tabular}

HFNC: High flow nasal cannula, SD: Standard deviation, $\mathrm{pH}$ : Power of hydrog 
Table 4. Comparison of successful and unsuccessful groups in HFNC therapy

\begin{tabular}{|c|c|c|c|c|}
\hline & & \multicolumn{3}{|l|}{ Results } \\
\hline & & Successful & Unsuccessful & $\mathbf{p}$ \\
\hline \multirow{2}{*}{ Gender } & Male & $25(52.1)$ & $14(73.7)$ & 0.106 \\
\hline & Female & $23(47.9)$ & $5(26.3)$ & \\
\hline Age (month) & & $39.2 \pm 46.8(21)$ & $32.2 \pm 52.7(5)$ & 0.159 \\
\hline Weight (kg) & & $12.8 \pm 11.2(7.75)$ & $9.1 \pm 10.2(6)$ & 0.109 \\
\hline \multirow[t]{7}{*}{ Underlying disease } & & $27(56.3)$ & $17(89.5)$ & 0.010 \\
\hline & Neurological disease & $16(33.3)$ & $8(42.1)$ & 0.500 \\
\hline & Liver disease & $1(2.1)$ & $0(0.0)$ & 1.000 \\
\hline & Cardiac disease & $6(12.5)$ & $7(36.8)$ & 0.038 \\
\hline & Immune deficiency & $1(2.1)$ & $0(0.0)$ & 1.000 \\
\hline & Malnutrition & $1(2.1)$ & $2(10.5)$ & 0.192 \\
\hline & Other & $2(4.2)$ & $0(0.0)$ & 1.000 \\
\hline \multirow[t]{3}{*}{ The reason for hospitalization in intensive care } & Respiratory failure & $44(91.7)$ & $19(100)$ & 1.000 \\
\hline & Heart failure & $2(4.2)$ & $0(0.0)$ & - \\
\hline & Shock & $2(4.2)$ & $0(0.0)$ & - \\
\hline \multirow{2}{*}{ Respiratory failure type } & Type 1 & $28(60.9)$ & $12(63.2)$ & 0.863 \\
\hline & Type 2 & $18(39.1)$ & $7(36.8)$ & - \\
\hline
\end{tabular}

HFNC: High flow nasal cannula

Table 5. Mean-standard deviation- $95 \%$ minimum-maximum levels of vital signs and blood gas changes before and after HFNC

\begin{tabular}{lllll} 
& \multicolumn{5}{l}{$\mathbf{9 5 \%} \mathbf{C l}$} \\
\hline $\begin{array}{l}\text { Difference before and } \\
\text { after HFNC }\end{array}$ & Mean \pm SD & Min & Max & p \\
\hline Respiration rate & $7.30 \pm 14.74$ & $2.97-$ & 11.62 & 0.001 \\
Heart rate & $19.03 \pm 26.32$ & $9.38-$ & 28.69 & $<0.001$ \\
Systolic blood pressure & $-9.00 \pm 13.79$ & $-13.19-$ & -4.81 & $<0.001$ \\
Retraction & $0.77 \pm 0.44$ & $0.50-$ & 1.03 & 0.002 \\
Oxygen saturation & $-2.68 \pm 4.41$ & $-4.09-$ & -1.26 & 0.001 \\
Blood gases & $-0.06 \pm 0.14$ & $-0.10-$ & -0.01 & 0.011 \\
pH & & & & \\
PCO $_{2}$ & $5.69 \pm 19.89$ & $-0.36-$ & 11.73 & 0.086 \\
PO $_{2}$ & $-15.71 \pm 71.92$ & $-38.71-$ & 7.29 & 0.175 \\
HCO $_{3}$ & $-1.18 \pm 4.27$ & $-2.48-$ & 0.12 & 0.073 \\
Lactate & $0.56 \pm 1.54$ & $0.03-$ & 1.09 & 0.080 \\
Saturation & $-7.83 \pm 17.59$ & $-13.38-$ & -2.28 & 0.016 \\
\hline
\end{tabular}

HFNC: High flow nasal cannula, SD: Standard deviation, Cl: Confidence interval

6. Respiratory rate, heart rate, systolic blood pressure, retraction and saturation values between the two groups were not statistically different. There was no statistical difference performed between two groups in blood gas parameters of $\mathrm{pH}, \mathrm{PO}_{2}, \mathrm{HCO}_{3}$, lactate and saturation values. In the unsuccessful group, the mean $\mathrm{PCO}_{2}$ in blood

\begin{tabular}{|c|c|c|c|}
\hline & Successful & Unsuccessful & $\mathbf{p}$ \\
\hline Respiration rate & $42.1 \pm 15.3(42)$ & $46.6 \pm 18.6(47)$ & 0.333 \\
\hline Heart rate & $150.1 \pm 24.2(151)$ & $146.5 \pm 29.6(146)$ & 0.633 \\
\hline $\begin{array}{l}\text { Systolic blood } \\
\text { pressure }\end{array}$ & $104.0 \pm 15.7(103)$ & $99.3 \pm 24.6$ (99) & 0.396 \\
\hline Retraction & $1.68 \pm 0.58(2)$ & $2.00 \pm 0.00(2)$ & 0.160 \\
\hline Oxygen saturation & $95.2 \pm 5.2(97)$ & $97.0 \pm 4.4(100)$ & 0.170 \\
\hline $\begin{array}{l}\text { Blood gases } \\
\mathrm{pH}\end{array}$ & $7.37 \pm 0.11(7.38)$ & $7.33 \pm 0.20(7.39)$ & 0.957 \\
\hline $\mathrm{PCO}_{2}$ & $42.8 \pm 15.8(41)$ & $55.3 \pm 24.8(49.5)$ & 0.039 \\
\hline $\mathrm{PO}_{2}$ & $87.3 \pm 58.8(66)$ & $76.7 \pm 38.9(64)$ & 0.898 \\
\hline $\mathrm{HCO}_{3}$ & $23.4 \pm 5.7(24)$ & $27.6 \pm 9.1(27)$ & 0.075 \\
\hline Lactate & $2.37 \pm 1.62(1.6)$ & $1.86 \pm 1.40(1.4)$ & 0.203 \\
\hline Saturation & $86.3 \pm 15.6(93.5)$ & $82.6 \pm 16.5(87)$ & 0.362 \\
\hline
\end{tabular}

HFNC: High flow nasal cannula

gas before HFNC was found to be statistically significantly higher than the patients who succeeded $(\mathrm{p}=0.039)$.

\section{Discussion}

HFNC therapy has been widely used in adults in recent years. In adults, HFNC therapy is used due to acute hypoxemic 
respiratory failure, post-extubation respiratory support, oxygenation before intubation or before bronchoscopy, postoperative respiratory failure and acute pulmonary edema. Many studies of HFNC therapy in bronchiolitis in children have been reported. In addition, there have been studies reporting usage of HFNC therapy for asthma, sleep apnea, pneumonia, critical child patient transport, and postextubation respiratory support (9). The number of studies in the literature on HFNC therapy in the pediatric intensive care unit is very low.

In our study, 67 patients received HFNC treatment within 1 year. In our study, $71.6 \%$ of our patients benefited from HFNC therapy. In the study conducted by McKiernan et al. (10) it was showed that intubation rates of patients decreased from $23 \%$ to $9 \%$ with HFNC therapy. In the retrospective study of Schibler et al. (11), which was performed on intensive care patients with viral bronchiolitis, it was observed that the intubation rates of patients decreased from $37 \%$ to $7 \%$ with HFNC therapy.

We conducted our study in a heterogeneous group of patients (underlying disease, reason for hospitalization in intensive care, respiratory failure type, etc.). $65.7 \%$ of patients had an underlying disease. The most underlying disease was neurological disease with the rate of $35.8 \%$. Cardiac disease was the second most frequent with the rate of $19.4 \%$. $94 \%$ of our patients received HFNC therapy due to acute respiratory failure, $3 \%$ due to acute heart failure and $3 \%$ due to shock. $61.5 \%$ of patients with respiratory failure were in type 1 (hypoxic) respiratory failure. HFNC treatment failure rate was higher in patients with underlying disease. In similar studies conducted earlier, failure rates were reported to be high in patients with underlying disease $(2,12,13)$.

Many studies have been reported in the literature showing improvement in patients vital signs and blood gas values after HFNC therapy (14-17). In our study, a statistically significant decrease was found in the respiratory rate, heart rate and retraction levels of patients after HFNC therapy. Similarly, there was a statistically significant increase in $\mathrm{pH}$ and saturation levels from blood pressure, oxygen saturation, blood gas evaluations.

There are scarce data on non-invasive respiratory support for pediatric patients who develop respiratory failure after extubation $(2,12)$. In our study, the success rate of patients who received HFNC therapy postextubation was $75 \%$.

\section{Study Limitations}

I would like to inform you that it is a retrospective, nonrandomized study. It has not been done in a single patient group. Most of our patients had an underlying disease. Bilevel positive airway pressure and continuous positive airway pressure could be tried in the group that failed HFNC. Multi-center prospective and randomized controlled studies are needed on the use of HFNC in the pediatric intensive care units.

\section{Conclusion}

It is known that HFNC therapy has been used effectively in children in recent years, and it provides improvement in vital findings and blood gas parameters. In our study, 71.6\% of our patients benefited from HFNC therapy. We think that HFNC therapy should be used more frequently in pediatric intensive care units to prevent intubation in cases such as acute respiratory failure, heart failure and shock.

\section{Ethics}

Ethics Committee Approval: Ethics committee approval for this study was obtained from İstinye University (no:2/2020.K-036, date: 21.05.2020).

Informed Consent: Treatment consent was obtained from the relatives of all patients in the intensive care hospitalization.

Peer-review: Externally peer-reviewed.

Financial Disclosure: The author declared that this study has received no financial support.

\section{References}

1. Agency for Healthcare Research and Quality. Healthcare Cost and Utilization Project (HCUP) Nationwide Emergency Department Sample (NEDS) 2008. Rockville, MD: Agency for Healthcare Research and Quality. 2008.

2. Yaman A, Kendirli T, Ödek Ç, Ateş C, Taşyapar N, Güneş M, et al. Efficacy of noninvasive mechanical ventilation in prevention of intubation and reintubation in the pediatric intensive care unit. J Crit Care 2016;32(1):175-181.

3. Temel Köksoy Ö, Paksu MŞ, Yener N, Malhun Kaplan E. NonInvasive Mechanical Ventilation Practice in Pediatric Intensive Care Unit: A Retrospective Study. J Pediatr Emerg Intensive Care Med 2016;3(2):62-68.

4. Hull J. The value of non-invasive ventilation. Arch Dis Child 2014;99(11):1050-1054.

5. Thill PJ, McGuire JK, Baden HP, Green TP, Checchia PA. Noninvasive positive-pressure ventilation in children with lower airway obstruction. Pediatr Crit Care Med 2004;5(4):337-342.

6. Wilkinson D, Andersen C, O’Donnell CP, De Paoli AG. High flow nasal cannula for respiratory support in preterm infants. Cochrane Database Syst Rev 2011:CD006405. 
7. Kugelman A, Riskin A, Said W, Shoris I, Mor F, Bader D. A randomized pilot study comparing heated humidified high-flow nasal cannulae with NIPPV for RDS. Pediatr Pulmonol 2015;50(6):576-583.

8. Spentzas T, Minarik M, Patters AB, Vinson B, Stidham G. Children with respiratory distress treated with high-flow nasal cannula. J Intensive Care Med 2009;24(5):323-328.

9. Kwon JW. High-flow nasal cannula oxygen therapy in children: a clinical review. Clin Exp Pediatr 2020;63(1):3-7.

10. McKiernan C, Chua LC, Visintainer PF, Allen H. High flow nasal cannulae therapy in infants with bronchiolitis. J Pediatr 2010;156(4):634-638.

11. Schibler A, Pham TM, Dunster KR, Foster K, Barlow A, Gibbons $\mathrm{J}$, et al. Reduced intubation rates for infants after introduction of high-flow nasal prong oxygen delivery. Intensive Care Med 2011;37(5):847-852.

12. Gupta P, Kuperstock JE, Hashmi S, Arnolde V, Gossett JM, Prodhan $\mathrm{P}$, et al. Efficacy and predictors of success of noninvasive ventilation for prevention of extubation failure in critically ill children with heart disease. Pediatr Cardiol 2013;34(4):964-977.
13. Najaf-Zadeh A, Leclerc F. Noninvasive positive pressure ventilation for acute respiratory failure in children: a concise review. Ann Intensive Care 2011;1(1):15.

14. Spentzas T, Minarik M, Patters AB, Vinson B, Stidham G. Children with respiratory distress treated with high-flow nasal cannula. J Intensive Care Med 2009;24(5):323-328.

15. McGinley B, Halbower A, Schwartz AR, Smith PL, Patil SP, Schneider H, et al. Effect of a high-flow open nasal cannula system on obstructive sleep apnea in children. Pediatrics 2009;124(1):179188.

16. Pham TM, O'Malley L, Mayfield S, Martin S, Schibler A. The effect of high flow nasal cannula therapy on the work of breathing in infants with bronchiolitis. Pediatr Pulmonol 2014;50(7):713-720.

17. Söğütlü Y, Biçer S, Kurt G, Şah O, Namdar M, Tokaç S, et al. Outcomes of high-flow nasal cannula oxygen therapy on the vital signs of children with lower respiratory tract diseases. J Pediatr Emerg Intensive Care Med 2016;3(3):121-130. 